\title{
Strategic Level Implementation: Development Criteria for IBS Formwork System Readiness Framework (IBS FOSREF) for Malaysian Construction Industry
}

\author{
Mohd Nurfaisal Baharuddin ${ }^{1, *}$, Nur Fadhilah Bahardin ${ }^{1}$, Mohd Azian Zaidi ${ }^{1}$ and Mohd Reeza Yusof ${ }^{2}$ \\ ${ }^{1}$ Faculty of Architecture, Planning \& Surveying, Universiti Teknologi MARA, Perak Branch, Seri Iskandar Campus, 32610 Seri \\ Iskandar, Perak Darul Ridzuan \\ ${ }^{2}$ Faculty of Architecture, Planning \& Surveying, Universiti Teknologi MARA, Selangor Branch, Shah Alam Campus, 40450 Shah \\ Alam, Selangor Darul Ehsan
}

\begin{abstract}
The Industrialized Building System (IBS) was introduced by the Construction Industry Development Board (CIDB) are classified to precast concrete framing, panel and box systems, steel formwork systems, steel framing systems, prefabricated systems and block work system which is mainly components based systems and products (CIDB, 2007). According to Nawi (2011), the benefit of IBS formwork system implementation will lead to environmental friendly which reduce the harmful impact on the environment by better use of available resources and reuse of molds will affect less of waste materials. Since there is no theory about readiness factors of IBS formwork system in Malaysia, the stakeholders will not realize the significance of IBS formwork system. Most of the challenges factor in implementation of IBS formwork system is the attitude of Malaysian construction stakeholders which are un-readiness in facing of globalization era since it was already stated by IBS Roadmap (2003-2010). Hence, the goals of this research are to analyses the critical factors of driving or hindering the used of IBS formwork system in the Malaysian construction industry. A survey among 157 respondents which are construction personnel was employed for the study. The survey result shows that fifteen (15) identified factors for IBS formwork implementation are further ranked according to the average mean score perceived by construction personnel as follow: (F6: Government Initiative), (F12: Roles of Agencies), (F13: Procurement), (F7: Training), (F14: Incentives), (F15: Manufacturer Availability), (F11: Familiarity of IBS System), (F4: Qualified Technical Team), (F8: Cost \& Financial), (F3: IBS Score Index), (F1: Project Trend), (F10: Compliance of Policy), (F5: IBS Scoring Manual), (F9: Promotion) and (F2: Contractor Involvement). Other than that, the development of IBS Formwork System Readiness Framework (IBS FOSREF) incorporated with Strategic Level Implementation Mc Kinsey 7s for Malaysian Construction Industry which are the main outcome for this research could facilitate the Malaysian construction stakeholders to ensure IBS formwork system implementation will be success.
\end{abstract}

\section{Introduction}

According to [8], IBS defined as prefabricated component and on-site installation involved with various construction process in utilizing product, technique, component, or building system. IBS offered valuable benefits such as minimizing wastage, reducing unskilled worker, enhanced the environmental, better quality control and increase construction site cleanliness besides time consuming in construction can be reduced and given more organised and safer construction site. It was agreed by [27], the IBS concept are involved with the component that are manufactured in a controlled environment either in the factory, or on or off-site, assembled and positioned into a structure with minimal additional site works. Other than that, several characteristics of IBS required to be accepted as part of IBS which are equally crucial to assure the achievement of the listed benefits. The process involved by taking the parts of the building that are repetitive and difficult to cast on-site due to standard designed off site, assembly and positioning all the parts on site and involved with time consuming and labour intensive. The utilization of innovative and clean mould technologies are the initiatives in IBS implementation especially in on-site casting activities [9]. According to [6], IBS implementation can be explained in eight stages and the chronology of of IBS implementation in Malaysia are as shown in table 1 .

\subsection{IBS Formwork System}

According to [19], IBS formwork system, also known as steel formwork system are identify as Tunnel forms, beams and columns moulding forms, permanent steel formworks (metal decks). On the other hand, according to [7], formwork system in IBS considered as one of the low level or the least prefabricated IBS. The system generally involved in site casting and subject to structural quality control, high-quality finishes, and fast construction with less site labour and material requirement.

The IBS formwork using the material such as metal or steel, aluminium and plastic gained its popularity recently due to its flexibility of application in many projects, recyclable at many phase of construction and can be used in different types of design structure. The factor are giving a significance impact towards the importance of IBS formwork system applied in the Malaysian construction industry.

\footnotetext{
*orresponding author: mohdn468@perak.uitm.edu.my
} 
Table. 1. Chronology of IBS development in Malaysia

\begin{tabular}{|c|c|}
\hline $\begin{array}{l}\text { EARLY } \\
\text { CONSTRUCTION }\end{array}$ & $\begin{array}{l}\text { - } 5^{\text {th }} \text { Century: Gangga Negara, } \\
\text { Kedah } \\
-14^{\text {th }} \& 15^{\text {th }} \text { Century: Malay } \\
\text { Architecture } \\
\text { - } 16^{\text {th }} \text { Century: Portuguese } \\
\text { influence } \\
17^{\text {th }} \text { Century: Dutch influence } \\
18^{\text {th }} \& 19^{\text {th }} \text { Century: British } \\
\text { influence }\end{array}$ \\
\hline $\begin{array}{l}\text { INITIAL STAGE OF } \\
\text { PREFABRICATION }\end{array}$ & $\begin{array}{l}\text { 1960: Successfully implemented } \\
\text { in UK, Western and Eastern } \\
\text { European } \\
\text { - 1960: Introduced in Malaysia } \\
\text { 1963: Architect was sent to } \\
\text { Europe to learn IBS } \\
\text { - 1964: Architect was sent to } \\
\text { France for IBS exposure }\end{array}$ \\
\hline $\begin{array}{l}\text { DEVELOPMENT IN } \\
1964-1970\end{array}$ & $\begin{array}{l}\text { - } 2^{\text {nd }} \text { Malaysian Plan } 1960 \text { - } 1965 \text { : } \\
\text { Built affordable house at Jalan } \\
\text { Pekeliling } \\
\text { - 1965: Jalan Rifle Range, Penang } \\
\text { - 1964 - 1974: Edmonton, North } \\
\text { London }\end{array}$ \\
\hline $\begin{array}{l}\text { DEVELOPMENT IN } \\
1970 \mathrm{~s}-1980 \mathrm{~s}\end{array}$ & $\begin{array}{l}\text { - 1978: Prefabrication technology } \\
\text { ( Penang Government launched) } \\
\text { 1980: } 2800 \text { units of living } \\
\text { quarters at Lumut Naval Base } \\
\text { - Late } 60 \text { s and } 70 \mathrm{~s} \text { : Introduced } \\
\text { foreign systems }\end{array}$ \\
\hline $\begin{array}{l}\text { DEVELOPMENT IN } \\
1980 \mathrm{~s}-1990 \mathrm{~s}\end{array}$ & $\begin{array}{l}\text { - Early } 80 \text { s - 90s: Usage of } \\
\text { structural steel components } \\
\text { - 1984: } 36 \text { storeys Dayabumi } \\
\text { complex } \\
\text { - } 90 \text { s: Demand in precast concrete } \\
\text { system } \\
\text { 1981 - 1993: Low Cost houses } \\
\text { and high cost Bungalows in } \\
\text { Selangor }\end{array}$ \\
\hline $\begin{array}{l}\text { DEVELOPMENT IN } \\
1990 \mathrm{~s}-1998 \mathrm{~s}\end{array}$ & $\begin{array}{l}\text { 1994 - 1997: Hybrid IBS } \\
\text { application } \\
\text { 1999: CIDB formed IBS } \\
\text { Steering Committee }\end{array}$ \\
\hline $\begin{array}{l}\text { DEVELOPMENT IN } \\
1998-2008\end{array}$ & $\begin{array}{l}\text { - Private companies adopted IBS } \\
\text { 2000: Coordination of } \\
\text { dimensions and space } \\
\text { 2004: 50\% of IBS in } \\
\text { construction elements } \\
\text { - Nov 2003: IBS Roadmap } \\
\text { published } \\
\text { - IBS agenda further boosted in } \\
\text { 2004-2006 } \\
\text { 2006: Tax incentives and CIMP } \\
\text { 2006 - 2015 }\end{array}$ \\
\hline 2008 - CURRENT & $\begin{array}{l}\text { - Oct 2008 - May 2010: IBS } \\
\text { project awarded } \\
\text { - 2009: Registration scheme for } \\
\text { IBS } \\
\text { - 2011: IBS Roadmap 2011 - } 2015 \\
\text { 2013: IBS Company Status (AIS) }\end{array}$ \\
\hline
\end{tabular}

The Construction Industry Development Board (CIDB) Malaysia in 2006 reported that, the implementation of IBS formwork was relatively lower as compared to the other components of IBS system due to several issues related to high initial capital investment for pre-casters in purchasing new machinery, mould, transferring a foreign technology as well as highly wages of skilled workers; were reflected to the lower application of this system. Furthermore, knowledge in IBS formwork technology among the Malaysian construction industry stakeholder are still lower and these has given a negative implication in creating an understanding, awareness and readiness to applied IBS formwork system.

The sustainable formwork system provides a better speed of construction, lower life-cycle costs, almost indestructible and reducing the additional site work [8]; [14]; [16]. On the other hand, the IBS formwork technology can reduce various problems which comes from construction industry.

As a sustainable element technology, IBS formwork helped fulfil the basic goal of construction; time, resources and quality [8]. Nevertheless, the expectation in application of IBS formwork in construction industries is still unexpected. Even full effort given by CIDB of Malaysia by actively promoting the use of IBS in construction, the application by the stakeholder are still lower and relatively below the target. The stakeholders need to align with the paradigm shift from conventional construction process into a lean construction method [5].

\section{Problem Statements}

The IBS formwork are well known as the best alternative in completing the construction project by reducing the used of conventional formwork which was exposed to the additional site work in nature as well as to the construction waste that finally affected the time, cost and safety [10]. Nevertheless, the production of IBS formwork seems not achieved enough when their application still not rapidly embracing [10]. In fact, the implementation of this system will facilitate the Malaysian stakeholders especially the contractor in a way to reduce any harmful effects to the environment by achieving the sustainable agenda. Currently, the take up of IBS formwork was below than the target of IBS used as stated in the IBS Roadmap 2003-2010 [5] and the participation of contractors to involved in the IBS project is currently poor [14]. With regards on that scenario, the identification of critical factor and difficulties through empirical study is vital in way to overcome the shortcomings. In general, a critical factor is defined as the factors which contribute the ineffective result and achievement towards successful of building construction with considering of time, quality and cost.

In respecting to this scenario, the study on identification of critical factor and its difficulties for applying IBS formwork; will assists the Malaysian government to overcome the shortcomings. This can provide an alternative a solution to enhanced the uses of IBS formwork in the Malaysian construction industry. 


\section{Research Methodology}

For the first objective, to identify the critical factors that contribute to difficulties in adopting IBS formwork, literature review strategies being used for the data collection for in depth knowledge about IBS Formwork in Malaysia. The development of critical factor was confined to the literature published from 2003 onwards in academic journals and published proceedings. A thorough examination was carried out to develop in depth-understanding about which factors are likely to happen due to IBS formwork implementation.

A descriptive technique was adopted to validate factors and sub factors of IBS formwork implementation. The questionnaire was conducted on a sample of drawn from a database of contractor listed in the Construction Industry Development Board (CIDB) Malaysia. The fullscale survey was constructed among B01 (Pre-Cast Concrete Contractor) and B19 (IBS Formwork System Contractor) which focusing on technical construction personnel. A total of 400 copies of the questionnaires were delivered to the potential respondents by email and online survey. However, only 157 copies and response of the questionnaire were received. The response rate was $39.25 \%$ and consistent with the norm of $20-30 \%$ for most questionnaire surveys distribute in the construction industry [11].

The second objective is to propose the best possible factors for IBS formwork system in Malaysian Construction Industry and thirdly, to develop a IBS Formwork System Readiness Framework (IBS FOSREF) for Malaysian Construction Industry. Finally, all the data gathered will be synchronized with effective strategic implementation Mc Kinsey 7s [17] as to ensure a significance implementation by policy maker. The data from the first, and second objective of the study is basically will be used for the development of the framework. For this paper, only third and fourth objective was discussed.

\section{Finding and Discussion}

According to study been done by [2], there are fifteen (15) numbers of importance factor found in his study which been develop by conceptual framework after 1st phase of research part which are identifying of critical factors through extensive literature review was completed. The fifteen (15) factors as follow:

Discussing on the survey result, from the perspective of construction industry stakeholders, the majority of respondents highlights in sequence that (F6: Government Initiative) is the main importance factor which could lead to enhancement of IBS formwork implementation.
Table. 2. Survey Result

\begin{tabular}{|c|c|c|c|}
\hline Factor & Perception & Mean & $\begin{array}{c}\text { Overall } \\
\text { Ranking }\end{array}$ \\
\hline F1 & Project Trend & 4.07 & 11 \\
\hline F2 & Contractor Involvement & 3.78 & 15 \\
\hline F3 & IBS Score Index & 4.11 & 10 \\
\hline F4 & Qualified Technical Team & 4.15 & 8 \\
\hline F5 & IBS Manual & 4.00 & 13 \\
\hline F6 & Government Initiative & 4.66 & 1 \\
\hline F7 & Training & 4.39 & 4 \\
\hline F8 & Cost \& Financial & 4.11 & 9 \\
\hline F9 & Promotion & 3.96 & 14 \\
\hline F10 & Compliance of Policy & 4.04 & 12 \\
\hline F11 & Familiarity of IBS System & 4.17 & 7 \\
\hline F12 & Roles of Agencies & 4.46 & 2 \\
\hline F13 & Procurement & 4.42 & 3 \\
\hline F14 & Incentives & 4.39 & 5 \\
\hline F15 & Manufacturer Availability & 4.19 & 6 \\
\hline
\end{tabular}

\begin{tabular}{clr}
\hline Rating & \multicolumn{1}{c}{ Rating Scale } & Classification \\
\hline 1 & very low or extremely ineffective & $1.00 \leq$ Average Index Score $\leq, 1.50$ \\
2 & low or ineffective & $1.50 \leq$ Average Index Score $\leq, 2.50$ \\
3 & medium or moderately ineffective & $2.50 \leq$ Average Index Score $\leq, 3.50$ \\
4 & high or very effective & $3.50 \leq$ Average Index Score $\leq, 4.50$ \\
5 & very high or extremely effective & $4.50 \leq$ Average Index Score $\leq, 5.00$ \\
\hline & & Sources: Mc Coffer, 1997
\end{tabular}

Fig 1. Rating Scales and Classification (Mc Caffer, 1997)

Then, it followed by (F12: Roles of Agencies), (F13: Procurement), (F7: Training), (F14: Incentives), (F15: Manufacturer Availability), (F11: Familiarity of IBS System), (F4: Qualified Technical Team), (F8: Cost \& Financial), (F3: IBS Score Index), (F1: Project Trend), (F10: Compliance of Policy), (F5: IBS Scoring Manual), (F9: Promotion) and (F2: Contractor Involvement) [35]. With refer to the Figure 1, it can be summarized that the top five (5) ranking of IBS formwork which is F6, F12, F13, F7, F14 can be considered as some key importance criteria which classified as a 'Strategic Level Implementation' since the entire factor shows the government role and responsibility in a way to emphasize the utilization of IBS formwork. Since all the factors are linkages with policy makers responsibilities, a formulation of IBS FOSREF as stated by [2] at Figure 2 is believed to bring a significance impact to the IBS application in Malaysia context.

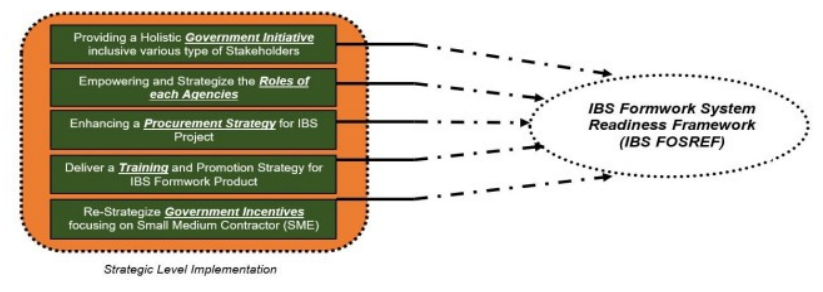

Fig 2. IBS Formwork System Readiness Framework (IBS FOSREF) for Malaysian Construction Industry

In order to ensure a successful implementation of IBS FOSREF by the government, it is recommended that the 
entire factors should be adapt with Effective Strategic Implementation, McKinsey 7-S model [17] which integrates strategy, structure, systems, staff, skills, style, and shared values and stated that interconnections among these 7 variables could facilitate a government to step ahead in bringing an IBS agenda.

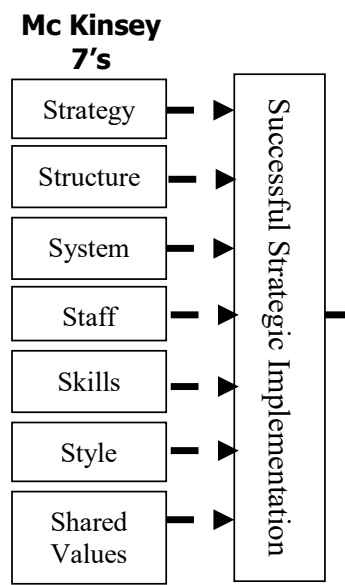

Fig 3. Strategic Implementation Models with Mc Kinsey 7's and IBS Formwork System Readiness Framework (IBS FOSREF) for Malaysian Construction Industry

The relationship between Mc Kinsey 7's [17] and IBS FOSREF can be categorized under several variables such as:

Strategy: As to strengthen the strategy of IBS formwork system, the type of procurement route and strategy that allowed adopters / stakeholders to be involve at the beginning such as during design and build.

Structure: The government shall allow a two way communication between IBS stakeholders and roles of each government agencies through a round table discussion as strengthening a current implementation of IBS.

System: It is pointed out that information technology (IT) is a vital an reliable tools to improve tendering, planning, monitoring, distribution, logistic and cost comparison processes by establishing integration, accurate and effective data dealing with project documents in IBS project. The aim of IT implementation is to enable joint up information management between government and IBS stakeholders to boost IBS implementation in Malaysia.

Staff: Training can be considered as integral part of an organisation learning and change. The primary rational for training between IBS workforce is to addressing skill deficiencies and to adapt employee's qualification to job requirement.

Skills: Indeed, it is imperative that an IBS stakeholder requires new skills and knowledge appropriately employed IBS workforce capable in installing IBS components.

Styles: A new approach and style of command in IBS formwork system can increase flexibility and versatility preferred by IBS practitioner due to its low setup cost compared to conventional system. A key strategy for
IBS Stakeholders are the ability to get volume and knowledge to manage the design, manufacturing and construction under 'one-roof' by moving from the contractor roles towards becoming a total provider solution to client. The SME's contractor can attempt to own the pre fabrication technology by devising a special relationship with one or more pre-fabrication subcontractor such as project based joint ventures, vertical integration or even internalisation. Meaning that, the IBS SME's must change their roles from existing contracting into IBS system integrator.

Shared Values: The pre-requisite depends to a large extent on the establishment of strategy, meeting of human capability and capacity and finally improve on the processes. The Government through their agencies shall give full support to all the IBS stakeholders in align with the business strategy, vision and mission of the national agenda with the desire to adopt IBS agenda.

\section{Conclusions}

In a nutshell, in a way to assure the Readiness among Malaysian Construction Stakeholders regarding the implementation of IBS Formwork, these five (5) factors should be in place and strategized by the government at 'Strategic Level' by adopting Mc Kinsey's 7s and IBS FOSREF. Thus, the roles of government agencies have play some significance roles to contribute a successful IBS Formwork implementation in Malaysia.

\section{References}

1. Azman, M. N. A., Majid, T. A., Ahamad, M. S. S., \& Hanafi, M. H. (2011b). A Study on the Trend of the Use of IBS Components and the Setting up of IBS Manufacturing Factories in the Malaysian Construction Industry. Malaysian Construction Research Journal, 9(2), 18-30.

2. Baharuddin, M. N., Bahardin, N. F., Zaidi, M. A., Lokman, I., Nawi. M. N. M, An Analysis of Key Importance Factor for IBS Formwork System among Malaysian Construction Stakeholders. MCRJ Special Issue, Vol. 2, No. 2, 2017, eISSN No. : 2590-4140 (2016)

3. Baharuddin, M. N., Bahardin, N. F., Zaidi, M. A., Lokman, I., Nawi. M. N. M (2016), "An Exploratory Review on Critical Factors of IBS Formwork implementation for Malaysian Construction Stakeholders", in International Soft Science Conference (ISSC 2016), Langkawi, 2016, AIP Conference Proceedings 020023 (2016).

4. Baharuddin, M. N., Bahardin, N. F., Zaidi, M. A., Yusof, M. R., Lokman, I. (2015), Identification of Critical Factors and Difficulties for Industrialised Building System (IBS) Formwork in Malaysian Construction Industry - A Literature Review, 2nd International Conference on Science and Social Research (CSSR 2015). 
5. Chung L.P. \& Kadir A.M, Implementation Strategy for Industrialized Building System. Master Thesis, Universiti Teknologi Malaysia (UTM), Johor Bahru (2007).

6. CIDB. An Introduction of Industrialised Building System. Manual for Developer Kuala Lumpur, MY: CIDB Malaysia (2014).

7. CIDB Malaysia (2007) Roadmap Review: Implementing The Ibs Roadmap 2003-2010, Construction Industry Development Board Malaysia (CIDB), Kuala Lumpur.

8. CIDB, National IBS Survey 2003, CIDB Malaysia, Kuala Lumpur (2003).

9. CREAM, Proceedings of 4th IBS Roundtable Workshop. Industrialised Building System (IBS): Towards Sustainable Implementation. Kuala Lumpur, MY: CREAM Malaysia (2011a)

10. Ghazali, M. A. A., IBS Plastic Formwork Application:Awareness and Readiness Factor among Malaysia Contractor. Degree Thesis, Universiti Teknologi MARA (UiTM) (2013)

11. J. Yang, G.Q. Shen, D.S. Drew and M. Ho. Critical Success Factors for Stakeholder Management: Construction Practitioners' Perspectives (Journal of Construction Engineering \& Management, Vol. 136, no.7,2010) pp. 778-86 (2010)

12. Haron, N. A., Rahman, H. A., \& Hanid, M. A Literature Review of the Advantages And Barriers To The Implementation Of Industrialised Building System (IBS) In Construction Industry. Malaysia Construction Research (2009).

13. Kamar, K. A. M., Alshawi, M., \& Hamid, Z. (2009a, January). Barriers to Industrialized Building System (IBS): The Case of Malaysia. In BuHu 9th Int. Postgraduate Research Conf. (IPGRC) (Vol. 471, p. 484). Research Institute for the Built and Human Environment, Univ. of Salford, Salford, UK.Journal, 2(1), 10-14.Dann, N and Cantell (2007), 'Maintenance in conservation in Forsyth, M. (Ed.), Understanding Historic Building Conservation', Blackwell, Oxford.

14. Nawi, M. N. M., Lee, A., \& Nor, K. M. Barriers to Implementation of the Industrialised Building System (IBS) in Malaysia. The Built \& Human Environment Review (Vol. 4, pp. 22-35) (2011).

15. Nawi, M. N. M., Azman, M. N. A., Baluch, N., Hamid, Z. A., (2015). 'Study on the Industrialised Building System (IBS) in Malaysian Private Construction Industry." Journal of Engineering and Applied Sciences (Vol. 10, No. 17., pp. 7368-7374).

16. Nazrol, A.A.K. Interview's Respondent, Officer from Construction Industry Development Board
(CIDB) Malaysia. Centre of IBS CIDB, Jalan Chan Sow Lin, Kuala Lumpur (2015).

17. R. S. Kaplan. How the balanced scorecard complements thebMcKinsey 7-S model. Strategy \& Leadership, Vol. 33, no. 3, pp. 41-46 (2005).

18. Zawawi, M. (2009). Effectiveness of Industrialized Building System (IBS) Implementation for Malaysian Construction Industry. Master of Science Thesis, Faculty of Civil Engineering Universiti Teknologi Malaysia.

19. Shaari S. N. (2003). Survey on the Usage of Industrialised Building Systems (IBS) in Malaysian Construction Industry. Kuala Lumpur, MY: CIDB Malaysia. 